\title{
Experimental Study on Gasification of Biomass Using a Pebble Bed Slagging Gasifier
}

\author{
Jian ZHANG and Kunio YOSHIKAWA \\ Department of Environmental Science and Technology, \\ Tokyo Institute of Technology \\ 4259 Nagatsuta-tyou, Midori-ku, Yokohama 226-8502, Japan
}

\begin{abstract}
A pebble bed gasifier is composed of entrained flow section and packed bed section of ceramic balls (pebble bed section), and it has three main features: high efficiency of slag capturing; assurance of long reaction time; and thermal buffer function of the pebble bed. High temperature air is used as an oxidant to obtain high enough temperature inside of the gasifier to melt ash and realize tar free gasification. Two kinds of biomass samples were used as fuels in the gasifiation experiments. These were dried wood chips and carbonized fowl droppings, corresponding to high and low volatile matter fuel, respectively. It was shown that the carbon conversion rates were $96 \%$ and $80 \%$, the cold gas efficiencies were $62 \%$ and $53 \%$ and the $H H V s$ were $5.49 \mathrm{MJ} / \mathrm{m}^{3} \mathrm{~N}$ and $3.50 \mathrm{MJ} / \mathrm{m}^{3} \mathrm{~N}$ for each biomass sample, respectively.
\end{abstract}

Keywords: Biomass, Gasification, Carbon conversion rate, Cold gas efficiency

\section{Introduction}

As a new source of energy, biomass has been a attracted research subject. By using the method of gasification, we have been carrying out the research on high efficiency energy extraction from biomass resources. The system employed in our study is called MEET

( Multi-staged Enthalpy Extraction Technology) which is shown in Fig. 1.

A high temperature air is used as an oxidizer in this system. Conventionally, in order to obtain syngas of high HHV, oxygen is used as an oxidizer. But if the oxygen is used as an oxidizer, costly equipments and energy are necessary to produce oxygen. Consequently, the using of a high temperature air as an oxidizer is one of the characteristics of the MEET system. Another feature is that a pebble bed gasifier where ceramic ball fixed bed

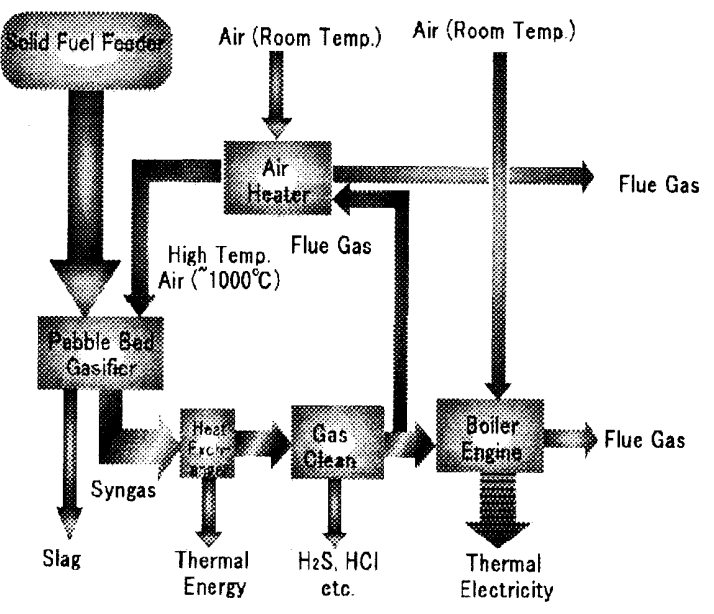

Fig.1 Concept of the MEET system

is installed under an entrained flow section is employed. The ceramic balls are called "pebbles". Three functions are expected for the pebble bed gasifier: 1) high 
efficiency slag capturing, 2) enhancement of gasification, 3) thermal stabilization. Figure 2 shows a schematic illustration of the pebble bed gasifier ${ }^{[1]}$

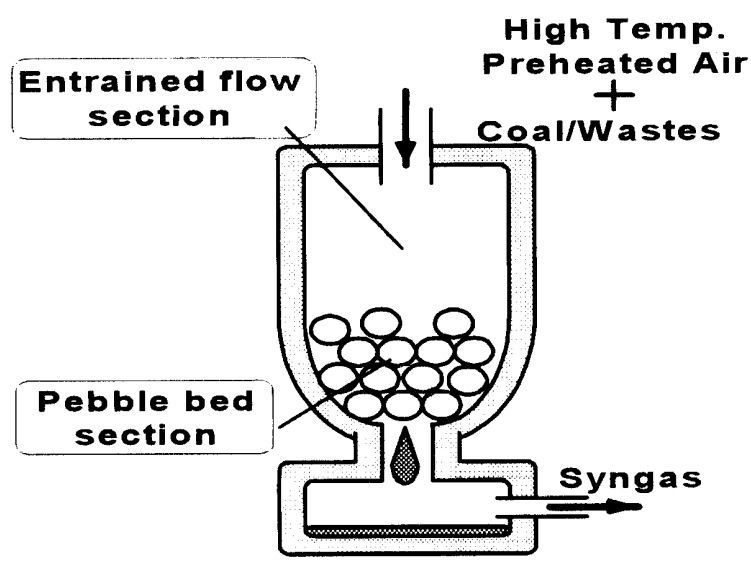

Fig2. Concept of a pebble bed gasifier

\section{Equipment}

The first MEET system used in our experiments is called MEET-I facility, which is shown in Fig.3. It consists of a pebble bed gasifier, a solid fuel feeder, a steam feeder, a filter, a heater, a water cooler, an induced draft fan (IDF) and an air compressor.

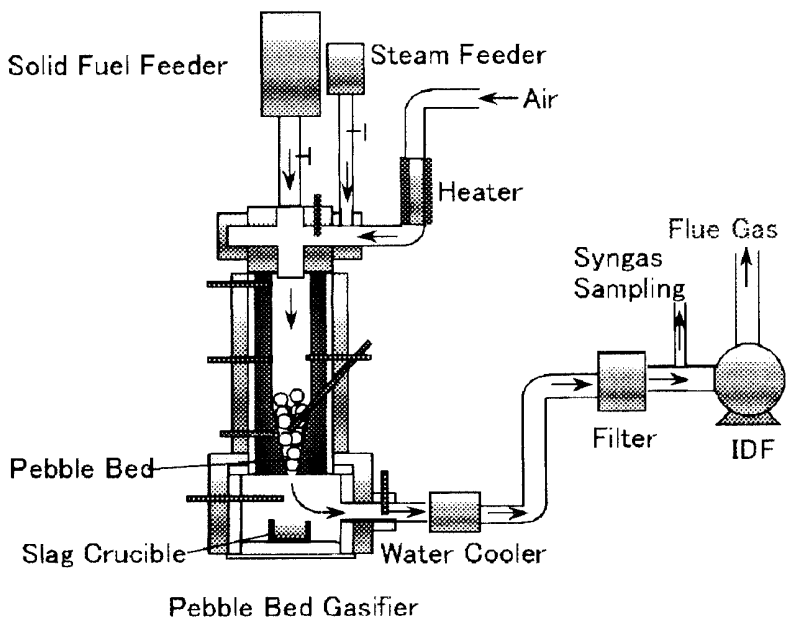

Fig.3 Schematic of the MEET-I facility

The most important components among these is the pebble bed gasifier. ${ }^{[2]}$ The pebble bed is made of 30 ceramic balls of $50 \mathrm{~mm}$ in diameter. The structure of the pebble bed gasifier is shown in Fig. 4.

\section{Operation}

To achieve the high temperature needed in gasification, we preheated the gasifier by using natural gas. For protecting the gasifier, the preheating rate was limited to $400 \sim 500{ }^{\circ} \mathrm{C} / \mathrm{h}$, which was controlled by monitoring the flow rate of natural gas. When the temperature of the bottom section of the gasifier exceeded the melting point of the ash of solid fuels, we shut down supply of natural gas and put the solid fuels into the gasifier. At the beginning of experiments, the air ratio was greater that 1.0 so that the solid fuel can be combusted completely until the temperature of the gasifier became stable. By controlling the air and steam flow rates, the gasification experiment was carried out. At the same time, the temperature in the gasifier was measured by thermocouples.

\section{Properties of fuel}

Two kinds of biomass samples were used as fuels in the gasification experiments. These were dried wood chips and carbonized fowl droppings, corresponding to high and low volatile matter fuel, respectively. The properties of the fuels are given in Table 1 .

Table 1. Properties of Fuel

\begin{tabular}{|l|c|c|c|}
\hline & & Wood Chips & $\begin{array}{c}\text { Carbonized } \\
\text { fowl } \\
\text { droppings }\end{array}$ \\
\hline Proximate Analysis & & & \\
\hline Moisture & wt\% & 7 & 3 \\
\hline Ash & $w t \%(d r y)$ & 0.6 & 34.6 \\
\hline Volatile Matter & $w t \%(d r y)$ & 83.4 & 21.3 \\
\hline Fixed Carbon & $w t \%(d r y)$ & 16 & 44.1 \\
\hline Total (dry) & & 100 & 100 \\
\hline HHV & MJ/kg & 20.0 & 18.1 \\
\hline LHV & MJ/kg & 17.2 & 16.8 \\
\hline Ultimate Analysis & & & \\
\hline C & $w t \%(d r y)$ & 51 & 48.3 \\
\hline H & $w t \%(d r y)$ & 6.1 & 2.1 \\
\hline N & $w t \%(d r y)$ & 0.1 & 3.9 \\
\hline O & $w t \%(d r y)$ & 42.3 & 10 \\
\hline Cl & $w t \%(d r y)$ & 0.1 & 1.1 \\
\hline S & wt (dry) & 0.1 & 0.6 \\
\hline
\end{tabular}




\section{Results and discussion}

Based on the analyzed value of fuels, no steam was added in gasification experiments for wood chips because they contain much water. Moreover, they contain so much volatile matter in the fuel that it is easy to be gasified. Consequently, the gasification experiments were carried out under the low air ratio. Oppositely, in the experiments using carbonized fowl droppings which contain little volatile matter and waer, it is expected that gasification is difficult. So $2 \mathrm{~kg} / \mathrm{h}$ steam was supplied into the gasifier and the gasification experiments were carried out under a relatively high air ratio.

First, the gasification experimental results of wood chips are shown in Table 2.

Table 2 Experimental conditions and results of wood

\begin{tabular}{|c|c|c|c|c|c|}
\multicolumn{7}{|c}{ chip gasification } \\
\hline Fuel & $\mathrm{kg} / \mathrm{h}$ & 7.0 & 7.0 & 7.0 & 10.0 \\
\hline Air & $\mathrm{m}^{3} \mathrm{~N} / \mathrm{h}$ & 7.3 & 8.9 & 8.9 & 14.0 \\
\hline Air Ratio & & 0.31 & 0.36 & 0.36 & 0.37 \\
\hline $\mathrm{H}_{2}$ & dry\% & 14.59 & 12.92 & 12.65 & 11.59 \\
\hline $\mathrm{O}_{2}$ & dry\% & 0.00 & 0.00 & 0.00 & 0.00 \\
\hline $\mathrm{N}_{2}$ & $\mathrm{dry} \%$ & 50.51 & 53.09 & 54.47 & 56.27 \\
\hline $\mathrm{CH}_{4}$ & $\mathrm{dry} \%$ & 2.24 & 2.16 & 1.76 & 1.68 \\
\hline $\mathrm{CO}$ & $\mathrm{dry} \%$ & 21.72 & 20.23 & 19.37 & 18.22 \\
\hline $\mathrm{CO}{ }_{2}$ & $\mathrm{dry} \%$ & 10.93 & 11.59 & 11.74 & 12.23 \\
\hline $\mathrm{HHV}$ & $\mathrm{MJ} / \mathrm{m}^{3} \mathrm{~N}$ & 5.49 & 5.06 & 4.76 & 4.44 \\
\hline $\mathrm{C} . \mathrm{C} . \mathrm{R}$. & $\%$ & 90 & 96 & 89 & 86 \\
\hline $\mathrm{C} . \mathrm{G.E}$. & $\%$ & 62 & 62 & 57 & 51 \\
\hline
\end{tabular}

To evaluate the gasification efficiency, carbon conversion rate (C.C.R.) and cold gas efficiency (C.G.E.) are determined by eqs. (1) and (2).

$$
\begin{aligned}
& \text { C.C.R. }=\frac{\text { Total Amount of Carbon in Syngas }}{\text { Total Amount of Carbon in Solid Fuel }} \times 100 \% \\
& \text { C.G.E. }=\frac{\text { Total Heating Value of Syngas }}{\text { Total Hearing Value of Supplied Fuel }} \times 100 \%
\end{aligned}
$$

In order to calculate the C.C.R., it is necessary to know the flow rate of the syngas. But it is difficult to masure the flow rate of the syngas directly because the gas composition fluctuates. Therefore, the nitrogen gas balance method was used in the calculation of the syngas flow rate with following assumptions.

1) Mole flow rate of nitrogen gas at the entrance ofthe gasifier is as same as that at the exit of the gasifier.

2) The only substances supplied into the gasifier are the fuel, air and steam.

3) The formation of nitrides can be ignored.

It can be seen from Table 2 that in each experiment, syngas containing heating value above $4.18 \mathrm{MJ} / \mathrm{m}^{3} \mathrm{~N}$ was obtained and the highest $\mathrm{HHV}$ is $5.49 \mathrm{MJ} / \mathrm{m}^{3} \mathrm{~N}$. The average value of the C.C.R. was greater than $90 \%$ and the maximum value was $96 \%$. The average value of the C.G.E. was about $57 \%$ and the maximum value was $62 \%$. Moreover, it can be seen that as the air ratio increased from 0.31 to 0.37 , the amount of combustible gases such as $\mathrm{H}_{2}, \mathrm{CO}$ and $\mathrm{CH}_{4}$ decreased (Other of $\mathrm{C}_{\mathrm{m}} \mathrm{H}_{\mathrm{n}} \mathrm{s}$ are not generated ).

Secondly, the gasification experimental results of carbonized fowl droppings are shown in Table 3. Under the condition of 0.49 of air ratio, although the carbonized fowl droppings contained low volatile matter, a syngas containing as high as $3.50 \mathrm{MJ} / \mathrm{m}^{3} \mathrm{~N}$ of $\mathrm{HHV}$ was obtained. The maximum value of the C.C.R. was as high as $80 \%$. The maximum value of the C.G.E. was about $53 \%$. It is considered that because of the presence of the pebble bed, carbonized fuel was captured on the pebble bed, which increased the residence time of the fuel in the gasifier.

Figure 5 shows the difference of temperature distribution in the gasifier for the two fuels during the gasification experiments. In the case of wood chips, the main reaction took place in the entrained flow section. 


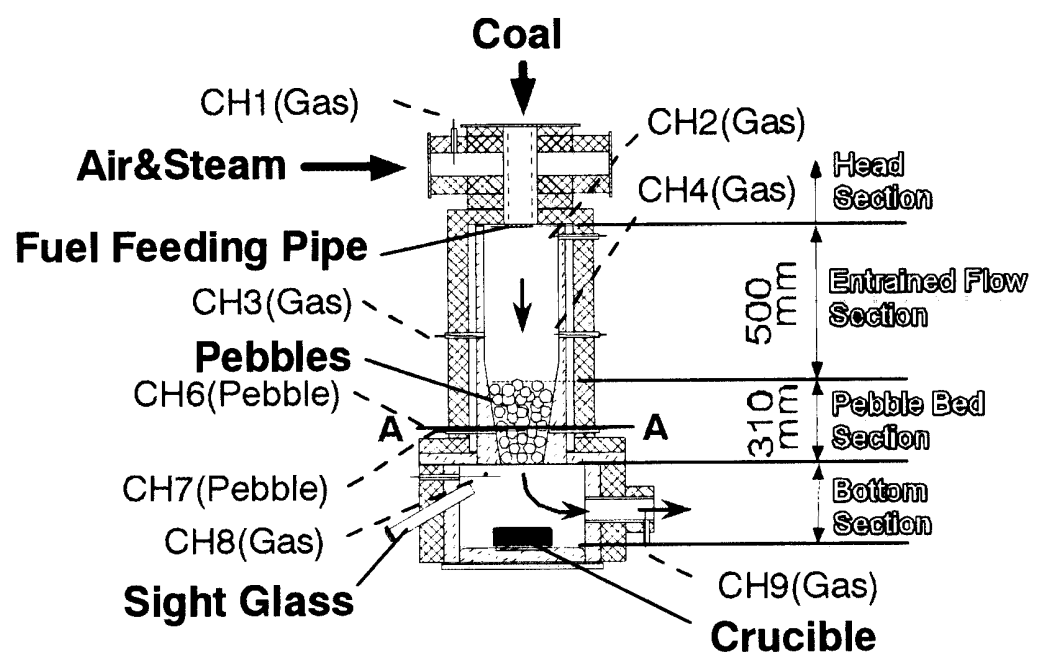

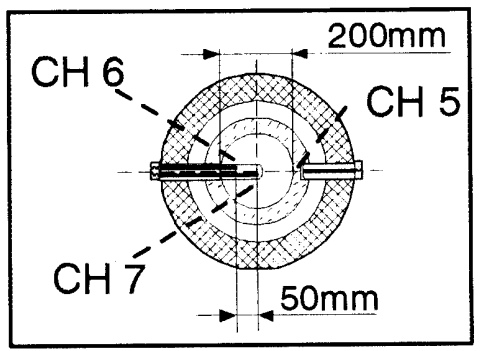

Sectional view (A-A)

$\mathrm{CH}$ : Thermocouple

Fig.4 Gasifier of the MEET-I facility

The highest temperature area in the gasifier located in the entrained flow section. On the contrary, in the case of carbonized fowl droppings, the main reaction took place in the pebble bed section. The highest temperature area in the gasifer located in the pebble bed section.

Table 3 Experimental conditions and results of carbonized fowl dropping gasification

\begin{tabular}{|c|c|c|c|}
\hline & & $\mathrm{T} 1$ & $\mathrm{~T} 2$ \\
\hline Fuel & $\mathrm{kg} / \mathrm{h}$ & 7.7 & 7.7 \\
\hline Air & $\mathrm{m}^{3} \mathrm{~N} / \mathrm{h}$ & 13.9 & 13.9 \\
\hline Steam & $\mathrm{kg} / \mathrm{h}$ & 2 & 2 \\
\hline Air Ratio & & 0.49 & 0.49 \\
\hline $\mathrm{H}_{2}$ & $\mathrm{dry} \%$ & 9.5 & 8.1 \\
\hline $\mathrm{O}_{2}$ & $\mathrm{dry} \%$ & 0.0 & 0.0 \\
\hline $\mathrm{N}_{2}$ & $\mathrm{dry} \%$ & 61.8 & 63.9 \\
\hline $\mathrm{CO}$ & $\mathrm{dry} \%$ & 17.9 & 16.8 \\
\hline $\mathrm{CO}{ }_{2}$ & $\mathrm{dry} \%$ & 10.6 & 11.1 \\
\hline $\mathrm{CH}{ }_{4}$ & $\mathrm{dry} \%$ & 0.1 & 0.0 \\
\hline $\mathrm{HHV}$ & $\mathrm{MJ} / \mathrm{m}^{3} \mathrm{~N}$ & 3.50 & 3.15 \\
\hline $\mathrm{C} . \mathrm{C} . \mathrm{R}$. & $\%$ & 80 & 76 \\
\hline $\mathrm{C} . \mathrm{G} . \mathrm{E}$. & $\%$ & 53 & 47 \\
\hline
\end{tabular}

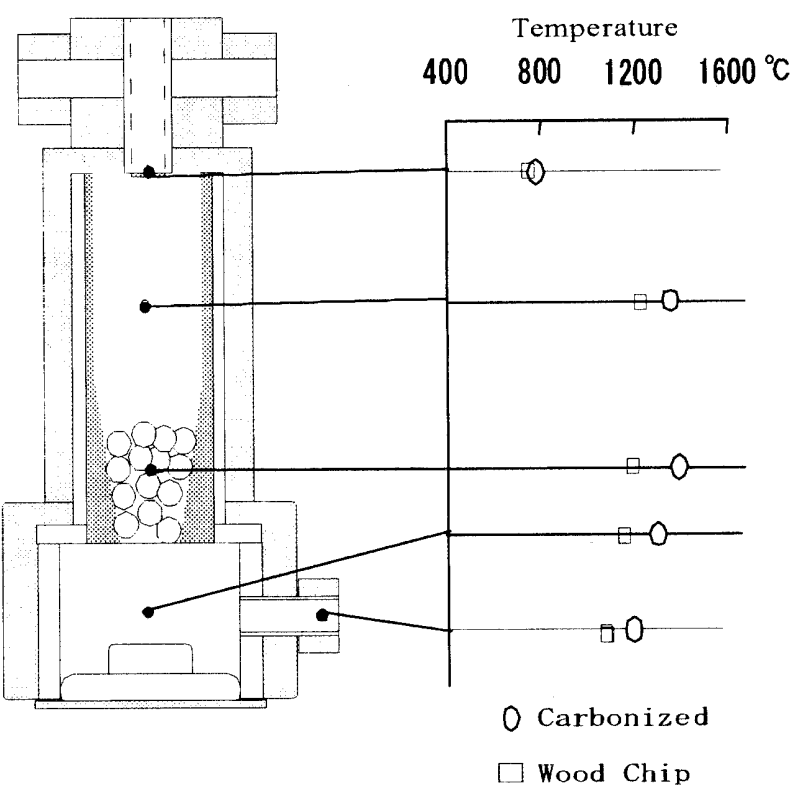

Fig. 5 Temperature distribution

\section{Conclusion}

We have carried out gasification experiments of two kinds of fuel successfully. The syngas that is usable for gas engine generator has been obtained. As the results, in the experiment for wood chips, the carbon conversion rate of $96 \%$, the cold gas efficiencies of $62 \%$ and the $\mathrm{HHV}$ of $5.49 \mathrm{MJ} / \mathrm{m}^{3} \mathrm{~N}$ were obtained respectively. In the experiment for carbonized fowl droppings, the carbon conversion rate of $80 \%$, the cold gas efficiencies of $53 \%$ and the HHV of $3.50 \mathrm{MJ} / \mathrm{m}^{3} \mathrm{~N}$ were obtained respectively. When we changed the low volatile matter 
fuel to the high one, the main reaction area moved from the entrained flow section to the pebble bed section.

This fact demonstrates the function of the pebble bed.

\section{References}

[1] H.Kobayashi, et al, 1999, (Gasification Coal and Solid using High temperature air), Proc.of ECOS99, pp.317-321

[2] Y.Kato Doctoral thesis, Tokyo Institute of Technology, 2002 